\title{
Poor outcome in patients with acute leukemia on intensive chemotherapy and COVID-19
}

\author{
Claudia Núñez-Torrón $\mathbb{1}^{1} \cdot$ Valentín García-Gutiérrez $\mathbb{1}^{1}$ - María Concepción Tenorio-Núñez ${ }^{1}$ • \\ Gemma Moreno-Jiménez ${ }^{1}$ • Francisco Javier López-Jiménez ${ }^{1}$ • Pilar Herrera-Puente ${ }^{1}$
}

Received: 8 May 2020 / Revised: 14 May 2020 / Accepted: 27 May 2020 / Published online: 4 June 2020

(c) Springer Nature Limited 2020

\section{To the Editor:}

Malard et al. recently published an interesting work of the experience at the Saint-Antoine Hospital of 25 patients with hematologic disease and COVID-19 infection [1]. The median age of their cohort was 72 years. Overall, $80 \%$ had a lymphoid malignancy and $92 \%$ of patients had additional chronic comorbidities. Only four patients (16\%) had myeloid disease (all of them myelodysplastic syndromes on best supportive treatment). The rate of acute respiratory distress syndrome (ARDS) was 52\% with an estimated mortality at 1 month of $40 \%$. They concluded that hematologic patients were a high-risk population of severe COVID-19 infection. We found of interest the lack of acute myeloid leukemia (AML) patients in this series.

In patients with AML candidates to intensive chemotherapy infections remain one of the main causes of morbidity and mortality [2].

To our knowledge, there are no current data evaluating the impact of concomitant COVID-19 in AML patients candidates to intensive therapy, and thus recommendations of expert panels are followed based on the available data in nonhematological population [3-5]. In order to provide information regarding the prognosis of AML patients in the midst of COVID-19 pandemic, we have evaluated all AML candidate for intensive chemotherapy hospitalized in our institution.

Supplementary information The online version of this article (https:// doi.org/10.1038/s41409-020-0961-y) contains supplementary material, which is available to authorized users.

Valentín García-Gutiérrez

jvalentingg@gmail.com

1 Servicio de Hematología, Hospital Universitario Ramón y Cajal (IRYCIS), Madrid, Spain
On February 25, 2020, the first COVID-19 patient in Madrid was confirmed. As of this date an exponential increase of COVID-19-positive cases is being detected, causing a collapse in many hospitals and a heavy overload in intensive care units (ICUs). We considered a confirmed COVID-19 case a patient with compatible clinical symptoms and new pulmonary infiltrates on chest radiography plus a positive RT-PCR for SARS-CoV-2 obtained from a respiratory sample [6]. We reviewed eight patients with AML that received a total of nine intensive AML chemotherapy cycles in a tertiary care hospital of which four were confirmed cases. The baseline characteristics of the entire cohort are shown in Supplementary appendix 1. This work has been reviewed and approved by the Ramón y Cajal Hospital Ethics Committee.

Patients were hospitalized in different areas depending on COVID-19 status. All AML patients were in individual rooms irrespective of COVID-19 disease, with appropriate protective isolation due to neutrophil count $<500 / \mu \mathrm{L}$. COVID-19-positive patients were in a specific COVID-19 area, treated by a multidisciplinary team including infectious disease and hematology specialists.

Patients received antifungal prophylaxis with posaconazole during neutropenic period. Treatment change from posaconazole to liposomal amphotericin B was performed in those patients receiving lopinavir/ritonavir (L/R) due to potential pharmacological interactions. In context of febrile neutropenia an empiric combination with piperacillin-tazobactam or meropenem and amikacin was started despite RT-PCR result. Thereafter, antibiotics were tailored based on clinical evolution and microbial isolations.

Among negative COVID-19 cases, the incidence of febrile neutropenia was $80 \%$. Only one patient needed hemodynamic support and invasive mechanical ventilation (IMV) with complete recovery. There were no death events.

The incidence of febrile neutropenia among COVID-19positive patients was $100 \%$. Only one patient had a 
Table 1 Clinical evolution and management of COVID-19positive patients.

\begin{tabular}{|c|c|c|c|c|}
\hline Characteristics & Patient 1 & Patient 2 & Patient 3 & Patient 4 \\
\hline $\begin{array}{l}\text { Sars-Cov-2 diagnosis after } \\
\text { initiation QT }\end{array}$ & Yes & Yes & No & Yes \\
\hline $\begin{array}{l}\text { Radiology findings at } \\
\text { diagnosis }\end{array}$ & $\begin{array}{l}\text { Bilateral } \\
\text { pneumonia }\end{array}$ & $\begin{array}{l}\text { Bilateral } \\
\text { pneumonia }\end{array}$ & $\begin{array}{l}\text { Bilateral } \\
\text { pneumonia }\end{array}$ & $\begin{array}{l}\text { Bilateral } \\
\text { pneumonia }\end{array}$ \\
\hline $\begin{array}{l}\text { Hydroxychloroquine }^{\mathrm{a}} \\
\text { Total days }\end{array}$ & $\begin{array}{l}\text { Yes } \\
16 \text { days }\end{array}$ & $\begin{array}{l}\text { Yes } \\
5 \text { days }\end{array}$ & $\begin{array}{l}\text { Yes } \\
5 \text { days }\end{array}$ & $\begin{array}{l}\text { Yes } \\
10 \text { days }\end{array}$ \\
\hline $\begin{array}{l}\text { Lopinavir/ritonavir }{ }^{\mathrm{b}} \\
\text { Total days }\end{array}$ & $\begin{array}{l}\text { Yes } \\
16 \text { days }\end{array}$ & $\begin{array}{l}\text { Yes } \\
7 \text { days }\end{array}$ & $\begin{array}{l}\text { No } \\
\text { NA }\end{array}$ & $\begin{array}{l}\text { Yes } \\
10 \text { days }\end{array}$ \\
\hline $\begin{array}{l}\text { Azithromycin } \\
\text { Total days }\end{array}$ & $\begin{array}{l}\text { No } \\
\text { NA }\end{array}$ & $\begin{array}{l}\text { No } \\
\text { NA }\end{array}$ & $\begin{array}{l}\text { Yes } \\
4 \text { days }\end{array}$ & $\begin{array}{l}\text { No } \\
\text { NA }\end{array}$ \\
\hline $\begin{array}{l}\text { Corticosteroids } \\
\text { Total days }\end{array}$ & $\begin{array}{l}\text { Yes } \\
9 \text { days }\end{array}$ & $\begin{array}{l}\text { Yes } \\
3 \text { days }\end{array}$ & $\begin{array}{l}\text { Yes } \\
6 \text { days }\end{array}$ & $\begin{array}{l}\text { No } \\
\text { NA }\end{array}$ \\
\hline Dosing & $1 \mathrm{mg} / \mathrm{kg}$ & $250 \mathrm{mg}$ & $1 \mathrm{mg} / \mathrm{kg}$ & NA \\
\hline $\begin{array}{l}\text { Tocilizumab N } \\
\text { Doses }\end{array}$ & $\begin{array}{l}\text { Yes } \\
2 \text { doses }\end{array}$ & $\begin{array}{l}\text { No } \\
\text { NA }\end{array}$ & $\begin{array}{l}\text { Yes } \\
2 \text { doses }\end{array}$ & $\begin{array}{l}\text { NO } \\
\text { NA }\end{array}$ \\
\hline Dosing & $600 \mathrm{mg}$ & NA & $\begin{array}{l}600 \mathrm{mg} \text { first dose, } \\
400 \mathrm{mg} \text { after }\end{array}$ & NA \\
\hline IL-6 (pg/mL) & 535 & 14.6 & 437.23 & ND \\
\hline IL-6 (pg/mL) after tocilizumab & 113 & NA & NA & NA \\
\hline Hemodynamic support & No & No & Yes & No \\
\hline Respiratory support & NIMV & NIVM & IVM & $\begin{array}{l}\text { Conventional } \\
\text { oxygen therapy }\end{array}$ \\
\hline ICU & No & No & Yes & No \\
\hline RT-PCR negativization & No & No & No & Yes \\
\hline Death & Yes & Yes & Yes & No \\
\hline $\begin{array}{l}\text { Time from COVID-19 } \\
\text { diagnosis to death, days }\end{array}$ & 27 & 10 & 24 & NA \\
\hline
\end{tabular}

IL-6 Interleukin 6, $q d$ once daily bid, twice a day, $N A$ not applicable, $N D$ Not determinate. ${ }^{2}$ Dosing $400 \mathrm{mg}$ BID first day; $200 \mathrm{mg}$ BID after, ${ }^{\mathrm{b}}$ Dosing 400/100 mg BID, ${ }^{\mathrm{c} D o s i n g} 500 \mathrm{mg}$ QD. microbial isolation (E. faecium bacteremia) added to SARSCoV-2. COVID-19 diagnosis was made previous to chemotherapy initiation in one patient and after chemotherapy initiation in three patients (at days $+1,+6$, and +9 , respectively). Of these three, one had a negative RT-PCR determination prior to chemotherapy that turned out positive at day +1 . Following our institutional protocols for conventional COVID-19 patients, initial management included a combination of hydroxychloroquine plus $L / R$ or azithromycin. In patients with torpid clinical evolution corticosteroids and tocilizumab, if IL-6 levels were above $40 \mathrm{pg}$ / $\mathrm{mL}$, were prescribed. There were no severe side effects related to specific drugs for COVID-19 management (Table 1).

One patient received hydroxychloroquine and L/R without corticosteroids or tocilizumab. He only required transient conventional oxygen supplementation in the first days after COVID-19 diagnosis, presenting resolution of all symptoms and a negative RT-PCR control. The other three patients presented respiratory worsening despite antiviral treatment (two with hydroxychloroquine and L/R, and one with hydroxychloroquine and azithromycin), so corticosteroids were added in all three cases plus tocilizumab in two of three due to IL-6 levels of 535 and $437.23 \mathrm{pg} /$ $\mathrm{mL}$, respectively. The IL-6 level after administration decreased to $113 \mathrm{pg} / \mathrm{mL}$ in one patient and the other had no IL-6 control. Despite the use of corticosteroids and/or tocilizumab, three of three patients needed mechanical ventilation. One required IMV and hemodynamic support with vasoactive drugs. Two required noninvasive positivepressure ventilation, as they were not considered apt for IMV. The three patients finally died.

Among COVID-19-positive patients, no one had associated comorbidities apart from AML. In the Supplementary appendix 2 is available a description of clinical course and treatment prescribed for each patient.

We are reporting, to our knowledge, the first experience of AML patients receiving intensive therapy that suffered concomitant COVID-19 disease. Three of the four patients presented refractory ARDS and all finally died. We believe that the comparison with AML patients candidate for intensive chemotherapy without COVID-19 during same period of time provide relevant information about the impact of COVID-19 in this specially high-risk population. 
In other studies, performed in hospitalized patients, overall survival differed from 5.4 to $28 \%$ [7, 8]. Liang et al. published results in 18 cancer patients and concomitant COVID-19 infection showing an incidence of severe events of $39 \%$ (defined as the percentage of patients being admitted to the ICU requiring invasive ventilation, or death). Older age was the only risk factor for severe events with a median age of 63.1 years [9].

Malard et al. identified hematologic patients as a highrisk subgroup of COVID-19 complications but they did not report any AML patient [1]. Of interest, three out of four patients died; however, patient characteristics significant differ with our patients. Comparing with Malard cohort, our COVID-19-positive patients were younger (median age of 54.5 years) and with no concomitant comorbidities that could have been related with COVID-19 severity. Of the four patients with MDS, there is no information regarding subtype of MDS, of nevertheless, all of them had important comorbidities and had progressive disease in best supportive care at COVID-19 diagnosis. In our cohort, all patients were considered candidates to intensive chemotherapy. At COVID-19 diagnosis, three were receiving their first chemotherapy cycle and only one patient was receiving his first reinduction after refractoriness to $3+7$.

Best management of AML patients with COVID-19 under intensive chemotherapy remains challenging. It is remarkable that the three patients that received corticosteroids (and two of three also tocilizumab) presented respiratory worsening despite the use of these drugs. All needed mechanical respiratory support and finally died. Probably we need further experience in these patients to find out their role and also the suitable moment in the course of infection to start them.

Based on expert recommendation, there is no evidence for delaying chemotherapy in previous negative SARSCoV-2 patients, although, RT-PCR should be tested in all leukemia patients previous to chemotherapy. In our cohort, three patients were diagnosed after initiation of chemotherapy despite isolation and hygienic measures of our hospital, including one with a negative RT-PCR prior to chemotherapy that turned out positive at day +1 . In patients with positive RT-PCR before treatment, current recommendations are to hold therapy until resolution of symptoms and negative RT-PCR if possible. We believe that the data we are presenting support these recommendations [5].

\section{Compliance with ethical standards}

Conflict of interest The authors declare that they have no conflict of interest.

Publisher's note Springer Nature remains neutral with regard to jurisdictional claims in published maps and institutional affiliations.

\section{References}

1. Malard F, Genthon A, Brissot E, van de Wyngaert Z, Marjanovic Z, Ikhlef S, et al. COVID-19 outcomes in patients with hematologic disease. Bone Marrow Transplant. 2020. Available from: https:// doi.org/10.1038/s41409-020-0931-4.

2. Gudiol C, Aguilar-Guisado M, Azanza JR, Candel FJ, Cantón R, Carratalà $\mathrm{J}$, et al. Executive summary of the consensus document of the Spanish Society of Infectious Diseases and Clinical Microbiology (SEIMC), the Spanish Network for Research in Infectious Diseases (REIPI) and the Spanish Society of Haematology and Haemotherapy (SEHH) on the management of febrile neutropenia in patients with hematological malignancies. Enferm Infecc Microbiol Clin. 2020;38:174-81.

3. Gavillet M, Carr Klappert J, Spertini O, Blum S. Acute leukemia in the time of COVID-19. Leuk Res. 2020;92:106353.

4. Tallman M, Rolling C, Zappasodi P, Schiller G, Mannis G, Olin R, et al. COVID-19 and acute myeloid leukemia: frequently asked questions. 2020. https://www.hematology.org/covid-19/covid-19-a nd-acute-myeloid-leukemia.

5. Dillon R, Cahalin P, Cavenagh P, Craddock C, Dennis M, Freeman $\mathrm{S}$, et al. Recommendations for the management of patients with AML during the COVID19 outbreak: a statement from de NRCI AML Working Party. 2020. http://www.cureleukaemia.co.uk/page/ news/523/aml-working-party-covid-19-recommendations.

6. Adhikari SP, Meng S, Wu Y, Mao Y, Ye R, Wang Q, et al. Epidemiology, causes, clinical manifestation and diagnosis, prevention and control of coronavirus disease (COVID-19) during the early outbreak period: a scoping review. Infect Dis Poverty. 2020;9:29.

7. Zhou F, Yu T, Du R, Fan G, Liu Y, Liu Z, et al. Clinical course and risk factors for mortality of adult inpatients with COVID-19 in Wuhan, China: a retrospective cohort study. Lancet Lond Engl. 2020;395:1054-62.

8. Cao B, Wang Y, Wen D, Liu W, Wang J, Fan G, et al. A trial of lopinavir-ritonavir in adults hospitalized with severe Covid-19. N Engl J Med. 2020;382:1787-99.

9. Liang W, Guan W, Chen R, Wang W, Li J, Xu K, et al. Cancer patients in SARS-CoV-2 infection: a nationwide analysis in China. Lancet Oncol. 2020;21:335-7. 